\title{
PENTINGNYA PENERAPAN PENGELOLAAN KEUANGAN BAGI UMKM
}

\author{
Jeni Wardi ${ }^{1}$, Gusmarila Eka Putri ${ }^{2}$, Liviawati ${ }^{3}$ \\ ${ }^{1,2,3}$ Fakultas Ekonomi Universitas Lancang Kuning \\ Jln. D.I. Panjaitan KM 8 Rumbai Pekanbaru \\ E-mail : jeniwardi@unilak.ac.id \\ diterima: 16/9/2019; direvisi: 5/2/2020; diterbitkan: 26/3/2020
}

\begin{abstract}
The existence of the development of MSMEs in the Tenayan Raya District of Pekanbaru City really needs the attention of the government to move the economy in our country, but it turns out that this sector has not become an independent sector and so cannot be used as the foundation of the national economy. There are so many obstacles and problems related to this MSME. And generally the problem is financial management because MSME owners don't focus on doing it. The importance of this is done so that MSMEs can demonstrate their performance in managing MSME businesses transparently and accurately will have a good impact on MSME businesses, this condition is also carried out for the sustainability of the business going forward. Descriptive method used by the sample is the owner of MSMEs in Tenayan Raya District, Pekanbaru City is good. Samples in this study were taken by 25 respondents. This research is a case study. Data were collected using a questionnaire instrument and analyzed using qualitative descriptive analysis techniques. The results showed that the application of MSME financial management was still very poor in terms of budget use, recording, reporting and control. This condition causes business continuity cannot be guaranteed.
\end{abstract}

Keywords: MSMEs, capital, finance, performance, business prospects

\section{PENDAHULUAN}

Meskipun UMKM itu usahanya masih belum menjanjikan penghasilan yang layak, namun usaha ini menjadi tulang punggung perekonomian bangsa ini dan bahkan usaha ini juga pernah mengharumkan nama baik bangsa pada era krisis ekonomi. UMKM tetap eksis dan sangat berkontribusi dalam menopang dan menyediakan lapangan kerja bagi masyarakat. Selain itu juga usaha ini berpotensi menjadi usaha menengah dan bahkan usaha besar baik skala nasional maupun internasional. Namun hal ini sulit terwujud bila pemerintah tidak mengambil peranan dalam memajukannya dan juga perlu dungan banyak pihak yang salah satunya dari dunia akademik dalam rangka membuat usaha ini tetap eksis dan juga tetap dikelola dengan baik oleh para pengelolanya.
Saat ini UMKM yang ada di propinsi riau khususnya kota pekanbaru dalam rangka memberikan dukungan kepada usaha ini sebagaimana data menunjukkan bahwa di Pekanbaru terdapat 68.728 unit usaha dan menjadi terbanyak di Propinsi Riau diikuti dengan Kabupaten Kampar dan juga Kabupaten Indragiri Hilir. Sedangkan kabupaten lainnya seperti kabupaten Pelalawan, Kota Dumai dan Kabupaten Kuansing merupakan penyumbang paling kecil dari daerah yang ada di Propinsi Riau.

Di Kota Pekanbaru sektor perdagangan menjadi sektor yang paling dominan yang diusahakan oleh pada pengelola usaha UMKM itu sendiri. Diikuti dengan sektor jasa dan juga produksi dan industri. Hal ini karena kota Pekanbaru selain merupakan ibukota Propinsi Riau juga merupakan pintu masuk seperti pelabuhan dan bandara dari dalam maupun luar negeri, sehingga 
membuat sektor perdagangan menjadi sektor yang paling berpotensi untuk berkembang. Kemajuan yang dicapai kota Pekanbaru akan menjadi salah satu alasan pemerintah memberdayakan sektor UMKM ini.

Hari ini Umkm menghadapi masalah permodalan lebih dominan. Maka dari itu harus ada usaha untuk kerja sama dengan perbankan agar menumbuh kembang UMKM dalam mendapatkan berbagai kemudahan dan fasilitas lainya dalam pengajuan pinjaman modal. Persoalan suku bunga yang diberikan dari sektor perbankan kepada pengelola UMKM masih saja menjadi kendala yang berarti walaupun pemerintah sudah melaksanakan program KUR yang menetapkan bunga sampai $6 \%$ setahun dan ini masih dinilai belum sebanding dengan hasil usaha yang diperoleh UMKM tersebut, di samping itu syarat administrasi dan pengelolaan keuangan harus bankable, ini menambah rumit nya masalah yang dihadapi oleh UMKM.

Saat ini saja dengan perkembangan penduduk kota Pekanbaru dari data dinas kependudukan tahun 2019 mencapai 1,1 juta orang. Jumlah ini menjadi potensi tersendiri dalam UMKM untuk tumbuh dan berkembang, disampaing itu juga dengan perkembangan penduduknya menjadikan banyak tumbuh UMKM baru. Dengan perkembangan yang semakin maju dan seharusnya perkembangan umkm yang ada di kota Pekanbaru juga harus maju walau kenyataan tidak sesuai dengan harapan karena persoalan permodalan tadi.

Persoalan yang muncul di lapangan UMKM yang semakin banyak ini masih belum mampu tumbuh dan berkembang sesuai harapan, dimana dalam pelaksanaannya terdapat banyak faktor penyebab kondisi demikian, seperti kendala mengenai pengetahuan yang dimiliki pengelola usaha, juga berkenaan dengan kemampuannya mengelola usaha dan juga penerapan teknologi yang berkembang saat ini dan banyak faktor lainnya. Srikandi (2004) menjelaskan bahwa faktor kemampuan mengelola keuangan usaha menjadi faktor dominan penyebab kegagalan UMKM mengembangkan usahanya. Hal ini juga ditegaskan oleh Rahman, F. (2017) juga bahwa faktor modal manusia dalam mengelola usaha juga menjadi faktor penentu keberhasilan UMKM dalam mengembangkan usahanya. Keuangan yang dikelola dengan baik akan membuat usaha menjadi lebih transparan dan juga akuntabel dalam pengelolaan usahanya Ediraras (2010).

Berangkat dari persoalan tersebut, menarik untuk dibahas lebih mendetail berkenaan dengan pentingnya penerapan pengelolaan keuangan bagi UMK dalam rangka membuat usaha terus tumbuh dan berkembang sehingga para investor memiliki keyakinan untuk berinvestasi dalam bidang usaha yang ditekuni para pengelola usaha dan pada gilirannya akan memajukan UMKM itu sendiri.

\section{TINJAUAN PUSTAKA}

Berbicara masalah UMKM dan kemampuan pengelolanya mengelola keuangan menjadi pembicaraan menarik. Dimana perlu diketahui bahwa menurut UU No. 20 Tahun 2008 dijelaskan UMKM itu merupakan usaha yang terdiri dari usaha mikro, kemudian usaha kecil, dan usaha menengah. Usaha ini dimulai dari aset yang dimiliki mulai dari 50 juta hingga 10 milyar. Juga memiliki omset penjualan mulai dari 300 juta hingga 50 milyar.

Secara konseptual pengelolaan keuangan merujuk kepada konsep manajemen keuangan, dimana Handoko (2011) menjelaskan bahwa konsep manajemen lebih diarahkan bagaimana mencapai tujuan organisasi dengan menerapkan cara memperhatikan masalah rencana usaha, kemudian badan 


\section{Jurnal Ilmiah Ekonomi dan Bisnis}

Vol. 17. No.1, Maret 2020 : 56-62

EISSN : $2442-9813$

ISSN : $1829-9822$

organisasi, SDM, juga mengenai pengerahan sumber daya dan leadeship dalam pengawasan. Sedangkan konsep keuagan sebagaimana dijelaskan oleh Hartati (2013) bahwa pengelolaan keuangan berfungsi dalam hal pencarian modal usaha dalam rangka pengembangan usaha, kemudian pengalokasian modal usaha sehingga mendapatkan apa yang diharapkan usaha dalam bentuk laba.

Maksud dengan adanya pengelolaan keuangan ini antara lain diharapkan apabila keuangan dikelola dengan baik maka efektifitas dari pencapaian tujuan usaha dapat terwujud dengan baik dan juga pemanfaatan modal usaha dalam rangka mencapai laba dapat efisien digunakan. Hal ini sesuai dengan pendapat Agustinus (2014) bahwa melalui penerapan program yang tepat dalam mengelola keuangan akan mencapai efektifitas dan efisiensi dalam penggunaan sumber keuangan perusahaan.

Dalam rangka menggunakan keuangan perusahaan dapat dilakukan dengan beberapa proses penting, sebagaimana dijelaskan oleh Kusnadi (2005) bahwa keuangan dengan analisa yang tepat menjadi sebuah pondasi keuangan dalam perusahaan. Analisa ini dapat memberikan penglihatan mengenai sehat atau tidaknya keuangan perusahaan dan juga hal ini dapat dilihat dari empat hal utama dalam konsep pengelolaan keuangan perusahaan, antara lain: pertama perencanaan keaungan, kedua pencatatan keuangan, ketiga pelaporan keuangan dan keempat pengendalian keuangan.

Menurut Adisaputro (2011) bahwa anggaran dalam sebuah perusahaan menjadi sebuah dasar dalam pembiayaan perusahaan baik untuk tujuan operasional maupun tujuan investasi. Perencanaan itu sendiri adalah bagaimana para pengelola menemukan cara terbaik dalam rangka mencapai tujuan perusahaan dan juga dijelaskan oleh Kuswadi (205) bahwa melalui perencanaan bidang keuangan ini maka dapat dilakukan dengan cara melakukan penganggaran keuangan dan dilanjutkan dengan mengalokasikan anggaran sesuai dengan rencana yang dibuat.

Kedua berkenaan dengan usaha melakukan pencatatan keuangan dijelaskan oleh Adisaputro (2011) bahwa melalui usaha mencatat berbagai bentuk transaksi yang dilakukan perusahaan maka akan dijadikan dasar dalam melakukan pelaporan keuangan, pentingnya pencatatan ini lebih diarahkan dalam rangka melakukan rekam keuangan yang seharusnya memang dilakukan, sehingga pemasukan dan pengeluaran keuangan akan semakin jelas.

Ketiga adalah kegiatan pelaporan keuangan, hal ini dilakukan dalam usaha memberikan penilaian dari sebuah pelaksanaan dari kegiatan keuangan kepada pihak yang berkepentingan sebagaimana dijelaskan oleh Adisaputro (2011) bahwa kegiatan usaha harus dilaporkan dengan baik sehingga informasi mengenai kesehatan keuangan diperoleh.

Terkhir yakni yang keempat, pengendalian keuangan dapat dijelaskan bahwa sistem pengelolaan keuangan lebih mengarah kepada bagaimana mengendalikan keuangan untuk mampu membiayai semua keperluan perusahaan dalam rangka mendapatkan keuntungan. Hal ini dijelaskan oleh Adisaputro (2011) bahwa pengendalian keuangan ini dimulai dari awal, saat berjalan dan umpan balik dari penggunaan keuangan itu sendiri.

Sedangkan pengelolaan keuangan pada UMKM sebagaimana dijelaskan oleh Husnan (2000) bahwa usaha pengelolaan keuangan usaha kecil lebih diarahkan bagaimana secara teknis usaha itu dilakkan mulai dari bagaimana mencari sumber pendanaan usaha, kemudian diikuti dengan manajemen kas usaha dan juga bagaimana menghitung 
kebutuhan modal investasi untuk pengembangan usaha itu sendiri.

\section{METODE PENELITIAN}

Penelitian survei dilakukan dalam mencari jawaban dari penerapan pengelolaan keuangan pada UMKM, yakni dilakukan di Kota Pekanbaru dengan mengambil sampel sebanyak 25 orang pengelola usaha yang diambil secara purposive sampling. Data dikumpulkan dengan menggunakan kuesioner dan wawancara mendalam dan data dianalisis dengan menggunakan teknik deskriptif kualitatif.

\section{HASIL DAN PEMBAHASAN}

Data yang dipakai dalam riset ini adalah data yang didapat dari UMKM di Kecamatan Tenayan Raya. Data diambil melalui penyebaran kuesioner kepada UMKM di sekitar Kecamatan Tenayan Raya, responden yang ditargetkan adalah 30 UMKM. Data yang didapat dari penyebaran kuesioner adalah keberadaan UMKM di Kecamatan Tenayan Raya - Kota Pekanbaru dari hasil rekap kuesionar yang telah kami buat, dapat dilihat bahwa dari 30 UMKM yang secara umum usahanya kurang dari 2 tahun, yaitu pada hasil diatas ada 11 UMKM yang baru berjalan kurang dari 2 tahun sedangkan ada 4 UMKM yang usahanya udah jalan lebih dari 9 tahun. Selain itu, dari jumlah karyawan yang ada sebagian besar UMKM di Kecamatan Tenayan Raya tidak mempunyai karyawan berdasarkan tabel 7 di hasil ada sebanyak 13 UMKM yang tidak mempunyai karyawan, dan hanya 1 UMKM yang memiliki karyawan lebih dari 2. Pada 30 kuesioner tersebut sebagian besar responden berjenis kelamin laki laki yaitu sebanyak 22, sedangkan 8 nya adalah responden perempuan dan juga pendidikan terakhir yang memiliki UMKM di Kecamatan Tenayan Raya kebanyakan tamatan SMA/SMK sebanyak 14, disusul oleh tamatan SMP sebanyak 10, lalu SD sebanyak 5 dan ditutupi oleh lulusan D3 yang hanya 1 .

Pengelolaan keuangan UMKM di Kecamatan Tenayan Raya - Kota Pekanbaru dapat dilihat melalui 4 indikator menurut Kuswadi (2005) yaitu penggunaan anggaran, pencatatan, pelaporan, dan pengendalian.

Penggunaan Anggaran

Secara umum UMKM di Kecamatan Tenayan Raya - Kota Pekanbaru berdasarkan rata rata dari data rekapan kuesioner hanya 1 UMKM yang membuat penggunaan anggaran yaitu pada UMKM Candra Stiker dan sisanya yaitu 29 UMKM tidak membuat penggunaan anggaran, dengan alasan mereka beranggapan bahwa usaha yang mereka rintis masih keci jadi mereka tidak memiliki pemikiran mengenai rencana anggaran.

Secara khusus terdapat 10 pertanyaan pada kusioner yang disebar pada 30 UMKM di Kecamatan Tenayan Raya, data yang dijelaskan ini berdasarkan dari rekapan kuesioner yang telah kami buat. Pada poin pertama adalah perencanaan keuangan pada UMKM, hanya 1 UMKM yang melakukannya yaitu Ampera Cemeng yang berdiri pada tahun 2015. Sedangkan yang lainnya tidak memiliki perencanaan keuangan, mereka tidak memiliki fikiran untuk membuat perencanaan keuangan. Pada poin kedua yaitu perencanaan dalam penjualan produk atau penawaran jasa terdapat 4 UMKM yang melakukannya, selebihnya tidak karena UMKM lainnya tidak memilik rencana dalam menjual produknya atau menawarkan jasanya. Pada poin ketiga adalah melayani penjualan produk secara kredit terdapat 7 UMKM yang melakukannya, selebihnya tidak melakukan karena UMKM tersebut tidak mau dalam pembayaran mengenai kredit. Pada poin keempat adalah mengenai perencanaan laba terdapat 1 
Jurnal Ilmiah Ekonomi dan Bisnis

Vol. 17. No.1, Maret 2020 : 56-62

EISSN : $2442-9813$

ISSN : $1829-9822$

UMKM yang melakukannya, selebihnya bagi UMKM yang tidak melakukannya karena mereka tidak terlalu dalam menargetkat laba mereka. Pada poin kelima adalah perencanaan modal awal dalam mendirikan usaha terdapat 1 UMKM yang melakukannya yaitu Radja Taylor, 29 UMKM lainnya tidak melakukannya karena mereka berfikir dalam mendirikan usaha tidak memerlukan perencanaan modal. Pada poin keenam dan ketujuh adalah membandingkan perencanaan yang dibuat dengan actual atau kenyataan dan melakukan evaluasi apabila terjadi selisih actual dengan kenyataan tidak terdapat satupun UMKM yang melakukannya, karena mereka tidak berminat buat elakukan hal tersebut. Pada poin kedelapan yaitu memisahkan uang pribadi dan modal usaha terdapat 7 UMKM yang melakukannya, selebihnya tidak karena mereka berfikir akan repot jika dipisahkan. Pada poin kesembilan adalah cadangan kas untuk pengeluaran tak terduga terdapat 12 UMKM yang melakukannya sedangkan yang lainnya tidak melakukannya karena mereka berfikir hal tersebut tidak perlu dilakukan. Dan poin yang terakhir adalah membuat perencanaan program untuk masa depan terdapat 9 UMKM yang melakukannya, sedangkan sisanya belum terfikir tentang program masa depannya.

\section{Pencatatan}

Secara umum UMKM di Kecamatan Tenayan Raya - Kota Pekanbaru berdasarkan rata rata dari data rekapan kuesioner terdapat 3 UMKM yang pencatatan yaitu pada UMKM Toko Bangunan Kamparindo, Anisa_Koe, dan Boendina Mekar Jaya. Sedangkan 27 UMKM tidak membuat pencatatan dengan alasan mereka masih belum paham dengan pencatatan dan ada juga yang beranggapan bahwa dengan adanya pencatatan maka akan membuat urusan mereka menjadi repot dan juga sulit untuk dikerjakan karena mereka yang gak paham dalam membuatnya.

Secara khusus terdapat 9 pertanyaan pada kusioner yang disebar pada 30 UMKM di Kecamatan Tenayan Raya, data yang dijelaskan ini berdasarkan dari rekapan kuesioner yang telah kami buat. Pada poin pertama adalah pencatatan transaksi penjualan terdapat 7 UMKM yang melakukannya, sedangkan yang lainnya tidak melakukan pencatatan transaksi penjualan, mereka masih tidak memiliki fikiran untuk membuat pencatatan transaksi penjualan. Pada poin kedua pencatatan transaksi pembelian terdapat 3 UMKM yang melakukannya, selebihnya tidak karena UMKM lainnya tidak melakukan pencatatan transaksi pembelian. Pada poin ketiga adalah pencatatan transaksi penjualan secara manual terdapat 7 UMKM yang melakukannya, selebihnya UMKM tidak melakukan pencatatan transaksi penjualan secara manual. Pada poin keempat adalah pencatatan transaksi pembelian secara manual terdapat 3 UMKM yang melakukannya, selebihnya UMKM tidak melakukan pencatatan transaksi pembelian secara manual. Pada poin kelima dan keenam adalah pencatatan transaksi penjualan dan pembelian terdapat 3 dan 0 UMKM, sedangkan yang lainnya tidak melakukannya karena mereka berfikir dalam membuatnya sulit dan buang-buang waktu. Pada poin ketujuh dan kedelapan adalah mengenai rekapitulasi penerimaan dan pengeluaran kas tidak ada satupun UMKM yang melakukannya karena mereka masih awam dengan bahasa rekapitulasi.. Dan poin yang terakhir adalah membuat pencatatan transaksi penjualan dan pembelian dapat membantu pengelolaan keuangan terdapat 2 UMKM yang melakukannya, sedangkan sisanya tidak melakukannya. 
Pelaporan

Menurut Kuswadi (2005)

kegunaan laporan yang dibuat tidak hanya sekedar angka-angka tertulis tetapi memiliki informasi. Secara umum UMKM di Kecamatan Tenayan Raya Kota Pekanbaru berdasarkan rata rata dari data rekapan kuesioner tidak ada satu UMKM pun yang membuat pelaporan. Pada setiap poin yang ada seperti membuat laporan keuangan secara lengkap, laporan neraca, laporan laba rugi, laporan arus kas, maupun laporan lainnya. Mereka beralasan bahwa usaha yang mereka rintis tidak memerlukan laporan keuangan karena usaha mereka usaha kecil, mereka bisa mengelolanya tanpa membuat laporan keuangan tersebut.

\section{Pengendalian}

Secara umum UMKM di Kecamatan Tenayan Raya - Kota Pekanbaru berdasarkan rata rata dari data rekapan kuesioner tidak ada UMKM yang melakukan pengendalian karena sebagian besar dari UMKM tidak memiliki nota, jika pun ada mereka tidak menggunakannya dengan baik dan juga kebanyakan dari UMKM tidak melakukan prosedur penagihan secara kredit maupun penarikkan kas keluar, mereka masih awam dengan ilmu tersebut.

Secara khusus terdapat 5 pertanyaan pada kusioner yang disebar pada 30 UMKM di Kecamatan Tenayan Raya, data yang dijelaskan ini berdasarkan dari rekapan kuesioner yang telah kami buat. Pada poin pertama adalah prosedur penagihan pada penjualan secara kredit terdapat 7 UMKM yang melakukannya, sedangkan yang lainnya tidak melakukan prosedur penagihan pada penjualan secara kredit, karena 23 UMKM lainnya tidak melakukan penjualan secara kredit. Pada poin kedua, ketiga dan keempat mengenai penarikan kas keluar dan nota
30 UMKM tidak melakukannya karena mereka tidak paham mengenai penarikkan kas dan juga mereka tidak menggunakan nota dengan baik. Pada poin kelima adalah mengarsipkan nota penjualan barang dagang terdapat 1 UMKM yang melakukannya yaitu Toko Bangunan Kamparindo, sisanya sebanyak 29 UMKM tidak mengarsipkan nota penjualan barang dagang.

\section{KESIMPULAN DAN SARAN}

Berdasarkan uraian yang detail di atas, maka dapat ditarik beberapa kesimpulan antara lain pertama, bahwa keberadaan UMKM di Kecamatan Tenayan Raya - Kota Pekanbaru pemilik UMKM kebanyakan laki-laki dengan jenjang pendidikan terakhir SMA/SMK, serta banyak UMKM yang tidak memiliki karyawan dan juga banyak UMKM yang baru berdiri atau kurang dari 2 tahun. Kedua, penerapan Pengelolaan keuangan oleh UMKM di Kecamatan Tenayan Raya Kota Pekanbaru sangat jelek, banyak dari mereka yang tidak menerapkan dari 4 indikator yang ada seperti penggunaan anggaran, pencatatan, pelaporan, dan pengendalian. Pemilik UMKM tersebut yang tidak memiliki dasar mengenai ilmu akuntansi banyak yang tidak paham dengan melakukan indikator tersebut, ada juga yang beranggapan bahwa usaha yang mereka lakukan masih kcil, jadi tidak diperlukan adanya 4 indikator tersebut serta beranggapan bahwa melakukan 4 indikator tersebut akan merepotkan pemilik.

Adapun Saran yang dapat diberikan dalam penelitian ini adalah sebagai berikut: pertama, sebaiknya pemilik UMKM di Kecamatan Tenayan Raya lebih baik menerapkan 4 indikator yang telah ada agar dapat memberikan informasi yang sangat berguna bagi usahanya. Kedua, untuk dinas terkait seperti Dinas Koperasi dan UMKM, Dinas Perindustrian dan Perdagangan atau lembaga keuangan terkait lainnya seharusnya mengadakan pealtihan dan sosialisasi bagi UMKM agar mereka tahu 
Jurnal Ilmiah Ekonomi dan Bísnis

Vol. 17. No.1, Maret 2020 : 56-62

EISSN : $2442-9813$

ISSN : $1829-9822$

pentingnya 4 indikator tersebut dalam operasional usaha mereka dan dapat menambah pengetahuan serta bisa menyusun laporan keuangan sesuai Standar Akuntansi Keuangan. Ketiga, bagi penelit selanjutnya: memperluas wilayah penelitian, dan juga menambah jumlah responden UMKM di Kecamatan Raya Kota Pekanbaru, supaya bisa mendapatkan data yang semakin lengkap, sehingga hasil dari penelitian yang dilakukan akan lebih detail dan akurat serta mereview kembali kuesioner untuk dipakai pada penelitian berikutnya. Karena ada beberapa item pernyataan pada indikator pelaporan dan pengendalian yang makai istilah dibidang akuntansi sehingga responden kurang memahami arti pernyataan tersebut, jadi disarankan pada penelitian selanjutnya sebaiknya gunakan istilah lebih umum agar mudah dimengerti oleh responden.

\section{DAFTAR PUSTAKA}

Adisaputro, G., \& Anggarini, Y. 2011. Anggaran Bisnis. Yogyakarta: UPP STIM YKPN YOGYAKARTA.

Andreas. 2011. Manajemen Keuangan UKM. Yogyakarta: Graha Ilmu.

Bungin, Burhan. 2011. Penelitian Kualitatif Komunikasi, Ekonomi, Kebijakan Publik, dan Ilmu Sosial Lainnya. Jakarta: Kencana.

Cooper, Donald dan William Emory. 1996. Metode Penelitian Bisnis. Jilid 1.Jakarta: Erlangga.

Ediraras, Dharma. 2010. Akuntansi dan Kinerja UMKM. Jurnal Ekonomi Bisnis Nomor 2, Volume 15. Universitas Gunadarma.

Hartati, Sri. 2013. Manajemen Keuangan Untuk Usaha Mikro, Kecil dan Menengah
Hasyim, D. 2013. Kualitas Manajemen Keuangan Usaha Mikro Kecil Menengah (UMKM) Studi Kasus Pada Distribution Store (Distro) di Kota Medan. Jurnal Pendidikan Ilmu-ilmu Sosial Volume 5. Universitas Negeri Medan.

Husnan, Suad. 2000. Manajemen Keuangan Teori dan Penerapan (Keputusan Jangka Panjang). Yogyakarta: BPFE.

Kasmir. 2010. Pengantar Manajemen Keuangan. Jakarta: Prenadamedia Group.

Kuswadi. 2005. Cara Mudah Memahami Angka dan Manajemen Keuangan bagi Orang Awam. Jakarta: Elex Media Komputindo.

Rahman, F. (2017). Peran Modal Manusia Dan Modal Investasi Terhadap Nilai Produksi Industri Kecil Di Kota Pekanbaru. Jurnal Benefita: Ekonomi Pembangunan, Manajemen Bisnis \& Akuntansi, 2(1), 1-9.

Republik Indonesia. 2008. Undang-Undang Nomor 20 Tahun 2008 Tentang Usaha, Mikro, Kecil dan Menengah. Tambahan Lembaran Negara RI Tahun 2008. No 4866. Sekretariat Negara. Jakarta.

Srikandi, C., \& Setyawan, A. B. 2004. Analisis Penerapan Siklus Akuntansi pada Usaha Kecil dan Menengah di Daerah Istimewa Yogyakarta. Jurnal Ilmiah ESAI Volume 9.

Wahjono, Sentot. 2008. Manajemen Tata Kelola Organisasi Bisnis. Jakarta: PT Indeks. 